\title{
Freshwater Snails and Schistosomiasis Mansoni in the State of Rio de Janeiro, Brazil: II - Centro Fluminense Mesoregion
}

\author{
Silvana C Thiengo/ ${ }^{+}$, Monica A Fernandez, M Fernanda Boaventura, Sonia B Santos*, \\ Aline C Mattos
}

\begin{abstract}
Departamento de Malacologia, Instituto Oswaldo Cruz-Fiocruz, Av. Brasil 4365, 21045-900 Rio de Janeiro, RJ, Brasil
*Instituto de Biologia Roberto Alcântara Gomes, Laboratório de Malacologia, Universidade do Estado do Rio de Janeiro, Rio de Janeiro, RJ, Brasil
\end{abstract}

\begin{abstract}
During the course of a survey carried out from 2000 to 2001 in the Centro Fluminense Mesoregion of the State of Rio de Janeiro 22 molluscan species were found. Many of the records are new due to the dearth of previous studies. Concerning the snail hosts of Schistosoma mansoni, the most frequently encountered species was Biomphalaria tenagophila, as it occurred in all the surveyed municipalities. There are new records of Biomphalaria straminea and Biomphalaria peregrina which is regarded as a potential intermediate host. Drepanotrema lucidum and Antillorbis nordestensis were found to be shedding echinostome cercariae and strigid cercariae respectively. An account about the current schistosomiasis transmission sites in this Mesoregion is presented as well.
\end{abstract}

Key words: schistosomiasis mansoni - intermediate hosts - cercariae - Rio de Janeiro - Brazil

This study is the second of a series started in 1997 to map the distributional patterns of planorbid snails of the state of Rio de Janeiro. Collections were made from March, 2000 to May, 2001 in the the following municipalities of the Centro Fluminense Mesoregion: Areal, Comendador Levy Gasparian, Paraíba do Sul, Sapucaia and Três Rios (Microregion Três Rios); Cantagalo, Carmo and Cordeiro (Microregion Cantagalo-Cordeiro); Bom Jardim, Duas Barras, Nova Friburgo and Sumidouro (Microregion Nova Friburgo); Santa Maria Madalena, São Sebastião do Alto, and Trajano de Morais (Microregion Santa Maria Madalena).

The freshwater snail species listed include specimens collected by the authors as well as those in the collection of the Department of Malacology of Instituto Oswaldo Cruz. An account of the transmission sites of Schistosoma mansoni Sambon, 1907 in this Mesoregion, the distribution of the snail species of medical and veterinary importance, and various kinds of cercariae found are also presented.

\section{MATERIALS AND METHODS}

We have adopted the Brazilian Institute of Geography and Statistics (IBGE 1995) procedures in dividing the state of Rio de Janeiro in six mesoregions. The Centro Fluminense Mesoregion is $6,835 \mathrm{~km}^{2}$, constituting $15.6 \%$ of the state.

The molluscs were collected from diverse snail habitats including streams, rivers, marsh areas, drainage and sewage ditches, ponds, flood areas and irrigation canals

Financial support: CNPq, Faperj, Fiocruz

${ }^{+}$Corresponding author. Fax: +55-21-2280.5840. E-mail: sthiengo@ioc.fiocruz.br

Received 18 July 2001

Accepted 19 February 2002 from all 52 districts of the 15 municipalities. Since at least three different habitats were investigated in each of the districts, an average of 156 samples was obtained.

Live snails were kept at the laboratory for a month, in aquaria containing dechlorinated tap water and a thin layer of a 2:1 mixture of screened soil and ground oyster shells as a substrate. Snails were fed on fresh lettuce leaves. All the snails were exposed to artificial light at five day intervals to determine possible infection with trematode larvae. Cercariae were identified according to Schell (1970) and subsequently fixed in $70 \%$ ethanol, stained with chloridric carmine and mounted in Canada balsam.

The ten largest specimens of each mollusc sample were preserved in Railliet-Henry's fluid after relaxation in a $0.05 \%$ nembutal solution. Two were dissected under a stereomicroscope for identification purposes.

Samples of taxonomic importance were deposited at the Malacological and Helminthological Collections of Instituto Oswaldo Cruz.

The results of parasitological surveys carried out from 1996 to the first trimester of 2001 were obtained from the National Health Foundation (Funasa).

\section{RESULTS}

Table I shows the localities where the molluscan species were found in the surveyed area. The distribution of the three intermediate hosts of $S$. mansoni as well as that of Lymnaea columella Say, 1817, one of the intermediate hosts of Fasciola hepatica (Linné) in Brazil is shown in the Figure.

In all, 10 species of planorbids and 12 other freshwater gastropod species were found: Antillorbis nordestensis (Lucena, 1954); Biomphalaria glabrata (Say, 1818); Biomphalaria peregrina (d'Orbigny, 1835); Biomphalaria schrammi (Crosse, 1864); Biomphalaria straminea (Dunker, 1848); Biomphalaria tenagophila (d'Orbigny, 1835); Drepanotrema anatinum (d'Orbigny, 1835); Drepanotrema cimex (Moricand, 1839); Drepanotrema depressissimum (Moricand, 1839); 
TABLE I

List of species and the localities where they were found in the Centro Fluminense Mesoregion of the State of Rio de Janeiro

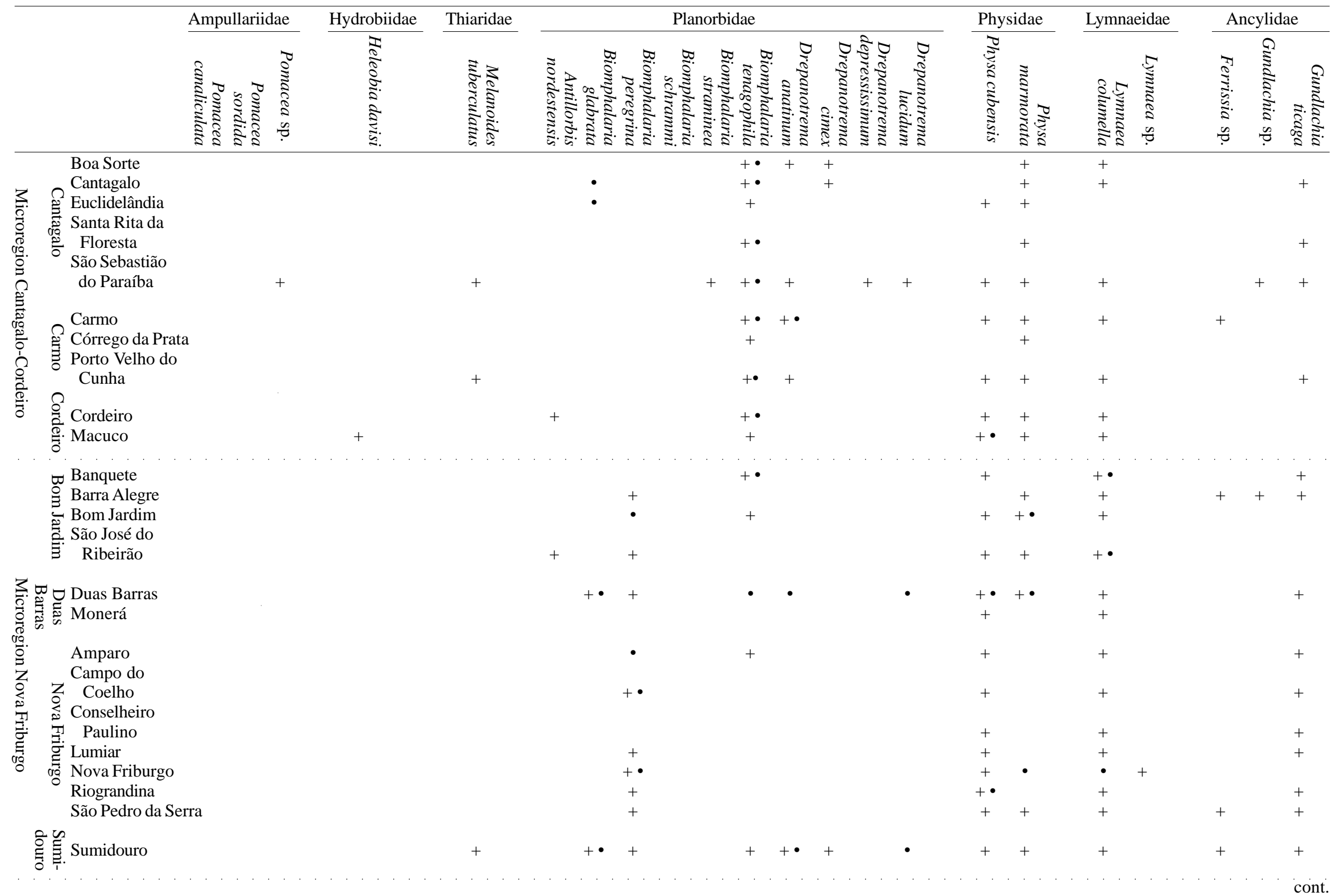




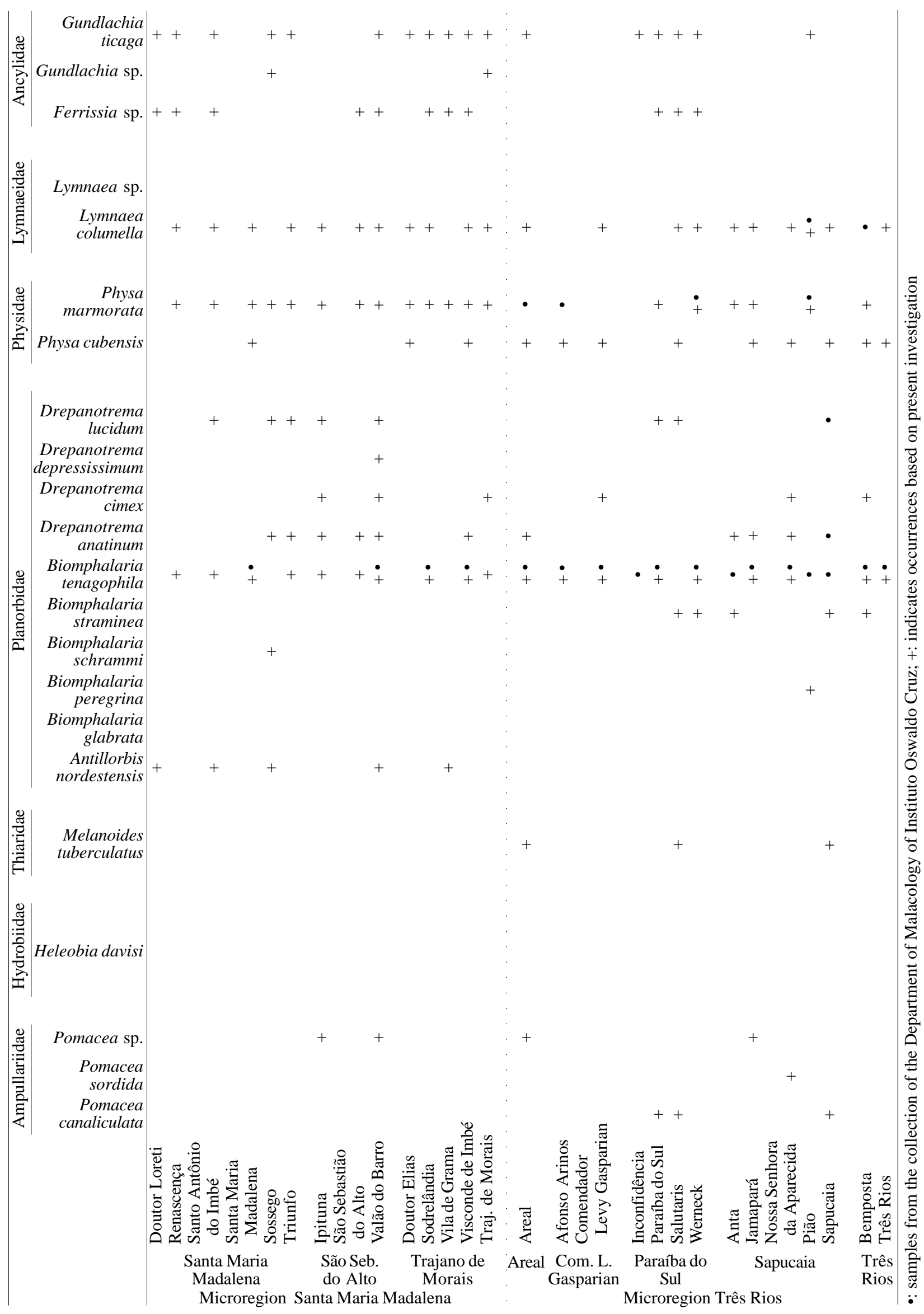




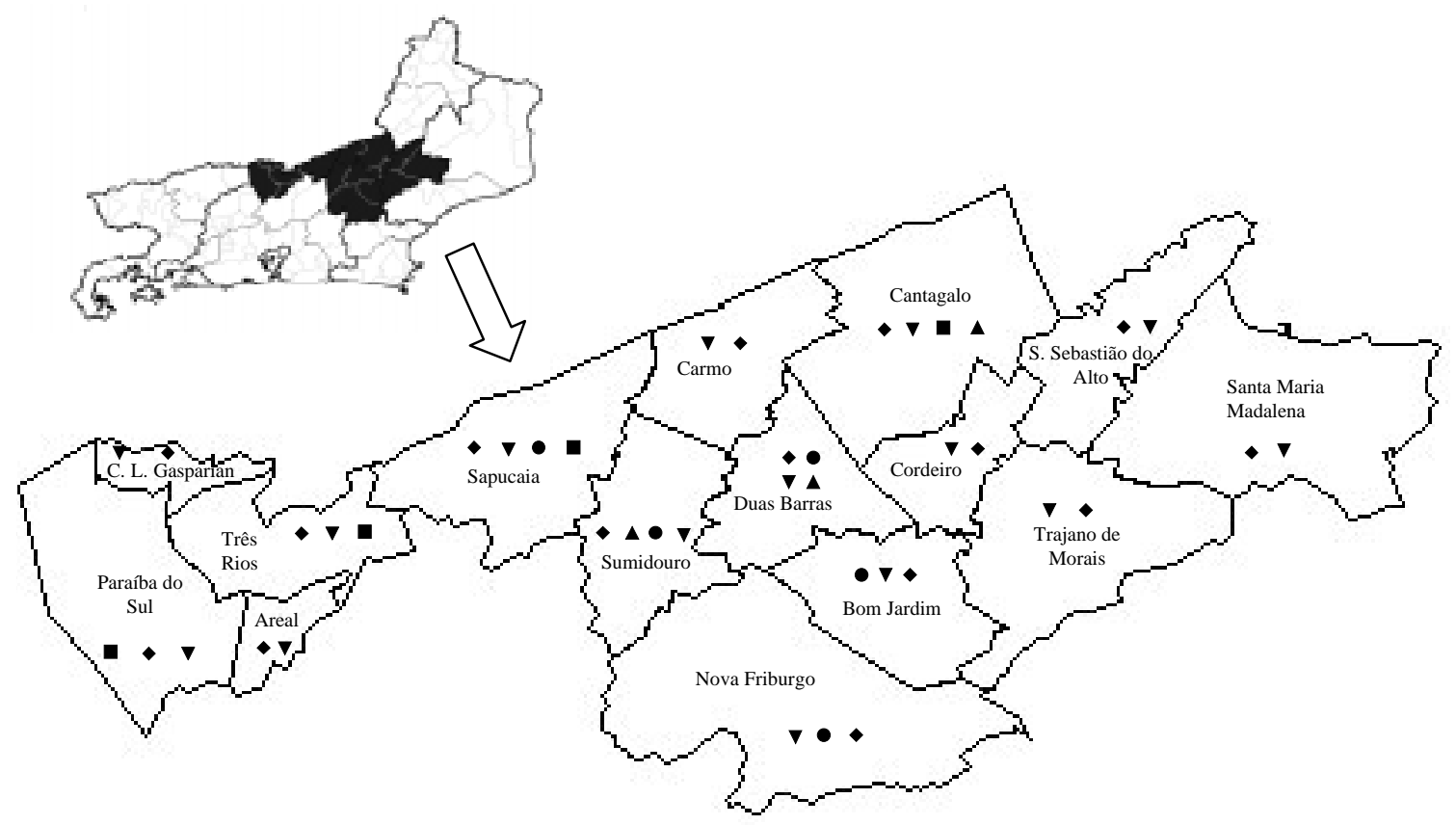

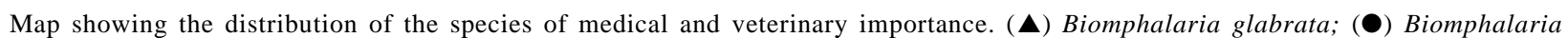

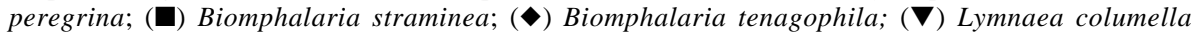

Drepanotrema lucidum (Pfeiffer, 1839); Ferrissia sp.; Gundlachia sp.; Gundlachia ticaga (Marcus \& Marcus, 1962); Heleobia davisi Silva \& Thomé, 1985; L. columella; Lymnaea sp.; Melanoides tuberculatus (Müller, 1774); Physa cubensis Pfeiffer, 1839; Physa marmorata Guilding, 1828; Pomacea sp.; Pomacea canaliculata (Lamarck, 1822) and Pomacea sordida (Swainson, 1823). The highest species richness occurred in the municipalities of Cantagalo and Sapucaia.

B. tenagophila harboured the greatest number of trematode larval types. They included: xiphidiocercariae, echinostome cercaria, strigid cercaria and metacercariae. Xiphidiocercariae were the most frequently encountered type of trematode larvae as they occurred in $B$. tenagophila, D. cimex, G. ticaga and L. columella. No cercariae of $S$. mansoni were encountered (Table II).

The results of parasitological surveys undertaken from 1996 to the first trimester of 2001 are shown in Table III. Most cases of schistosomiasis were from the municipalities of Carmo, Duas Barras and Sumidouro, which are known to be low transmission sites.

\section{DISCUSSION}

B. tenagophila, B. straminea and B. glabrata occurred only in Cantagalo. As observed by Paraense (1986) and Thiengo et al. (1998), B. tenagophila was the most frequent snail host species, as it occurred in all the surveyed localities.

The present paper also covers the distribution of both B. stramine a and B. glabrata in the state of Rio de Janeiro (Figure). B. straminea was previously recorded in $14 \mathrm{mu}-$ nicipalities (Paraense 1986, Thiengo et al. 1998, 2001) and the records for Cantagalo, Paraíba do Sul, Sapucaia, and Três Rios are new. B. glabrata has been previously recorded from Barra do Piraí, Duas Barras, Rio de Janeiro, and Sumidouro by Paraense (1972), but those for two districts of Cantagalo are new. The results of stool examination show that transmission is currently taking place in Duas Barras and Sumidouro, where the snail intermediate host is B. glabrata. This species is considered to be the most important host due to its widespread distribution and high susceptibility to infection by S. mansoni.

The distributional pattern of $B$. peregrina, considered a potential vector of schistosomiasis by Paraense and Corrêa (1973), has been extended to include Bom Jardim, Duas Barras, and Sumidouro. It was previously recorded in Barra do Piraí, Barra Mansa, Itatiaia, Nova Friburgo, Nova Iguaçu, Paraíba do Sul, Paulo de Frontin, Petrópolis, Resende, Sapucaia, Teresópolis, Três Rios, Valença, Vassouras, and Volta Redonda (Paraense 1966, Thiengo et al. 1998). B. schrammi was found only in Santa Maria Madalena, but was previously recorded in Cachoeiras de Macacu, Maricá, Nova Iguaçu, and São Gonçalo by Thiengo et al. (2001).

Of the remaining pulmonate species, the most frequently found was L. columella (43 districts), followed by $P$. marmorata (38 districts) and $P$. cubensis (31 districts). Specimens of an unidentified Lymnaea from Nova Friburgo resembled those described by Thiengo et al. (1998) from Teresópolis. Further anatomical studies of adult specimens from both municipalities are being undertaken to permit identification to species level. $D$. anatinum was found in 17 districts, followed by $D$. lucidum (11 districts), D. cimex (9 districts) and 
TABLE II

List of types of cercariae and the localities where they were found in the Centro Fluminense Mesoregion of the State of Rio de Janeiro

\begin{tabular}{|c|c|c|c|c|}
\hline \multirow[b]{2}{*}{ Municipality } & \multicolumn{2}{|c|}{ Trematode } & \multirow[b]{2}{*}{ Mollusc host } & \multirow{2}{*}{$\begin{array}{c}\% \text { of positive snails } \\
\text { (infected/total) }\end{array}$} \\
\hline & Larval stages & Possible family & & \\
\hline Cantagalo & Xiphidiocercariae & - & B. tenagophila & $7.5(3 / 40)$ \\
\hline Comen. Levy Gasparian & Xiphidiocercariae & - & B. tenagophila & $4.8(1 / 21)$ \\
\hline Cordeiro & Ornatae cercaria & Haplometridae or Macroderoididae & L. columella & $2.8(2 / 72)$ \\
\hline Nova Friburgo & $\begin{array}{l}\text { Echinostome cercaria } \\
\text { Xiphidiocercariae }\end{array}$ & $\begin{array}{l}\text { Psilostomatidae } \\
\text { - }\end{array}$ & $\begin{array}{l}\text { G. ticaga } \\
\text { G. ticaga }\end{array}$ & $\begin{array}{l}12.5(1 / 8) \\
12.5(1 / 8)\end{array}$ \\
\hline Santa Maria Madalena & Strigid cercaria & Strigeidae or Diplostomatidae & A. nordestensis & $8.7(2 / 23)$ \\
\hline São Sebastião do Alto & $\begin{array}{l}\text { Metacercariae } \\
\text { Strigid cercaria } \\
\text { Xiphidiocercariae }\end{array}$ & $\begin{array}{l}\text { - } \\
\text { Strigeidae or Diplostomatidae }\end{array}$ & $\begin{array}{l}\text { B. tenagophila } \\
\text { B. tenagophila } \\
\text { D. cimex }\end{array}$ & $\begin{aligned} & 14.8(4 / 27) \\
& 22(9 / 41) \\
& 46.3(31 / 67)\end{aligned}$ \\
\hline Sapucaia & Xiphidiocercariae & - & L. columella & $20(1 / 5)$ \\
\hline Trajano de Morais & $\begin{array}{l}\text { Echinostome cercaria } \\
\text { Echinostome cercaria } \\
\text { Ornatae cercaria } \\
\text { Xiphidiocercariae }\end{array}$ & $\begin{array}{l}\text { Echinostomatidae } \\
\text { Echinostomatidae } \\
\text { Haplometridae or Macroderoididae } \\
\text { - }\end{array}$ & $\begin{array}{l}\text { B. tenagophila } \\
\text { P. marmorata } \\
\text { P. marmorata } \\
\text { B. tenagophila }\end{array}$ & $\begin{aligned} & 3.4(7 / 208) \\
& 5.2(5 / 97) \\
& 2.1(2 / 97) \\
& 20.2(42 / 208)\end{aligned}$ \\
\hline Três Rios & $\begin{array}{l}\text { Echinostome cercaria } \\
\text { Strigid cercaria } \\
\text { Xiphidiocercariae } \\
\text { Xiphidiocercariae }\end{array}$ & $\begin{array}{l}\text { Echinostomatidae } \\
\text { Strigeidae or Diplostomatidae } \\
\text { - }\end{array}$ & $\begin{array}{l}\text { D. lucidum } \\
\text { B. tenagophila } \\
\text { B. tenagophila } \\
\text { L. columella }\end{array}$ & $\begin{aligned} & 12.5(1 / 8) \\
& 7.1(2 / 28) \\
& 17.9(5 / 28) \\
& 25(1 / 4)\end{aligned}$ \\
\hline
\end{tabular}

TABLE III

Number of positive cases ${ }^{a}$ of schistosomiasis in the Centro Fluminense Mesoregion of the State of Rio de Janeiro (after Fundação Nacional de Saúde report)

\begin{tabular}{lrrrrrr}
\hline & \multicolumn{6}{c}{ Year } \\
\cline { 2 - 7 } Municipality & 1996 & 1997 & 1998 & 1999 & 2000 & 2001 \\
\hline Bom Jardim & 1 & 0 & 0 & 0 & 0 & 0 \\
Cantagalo & 25 & 0 & 0 & 0 & 0 & 0 \\
Carmo & 0 & 13 & 14 & 11 & 2 & 0 \\
Duas Barras & 29 & 46 & 40 & 64 & 10 & 20 \\
Sumidouro & 36 & 18 & 31 & 17 & 9 & 16 \\
\hline
\end{tabular}

$a$ : total of tested people is unreported

D. depressissimum (2 districts). D. anatinum was also the most frequent species in the Metropolitan Mesoregion according to Thiengo et al. (2001). The distribution of A. nordestensis, previously known in 13 municipalities in the state (Thiengo et al. 1998, 2001, Santos et al. 1999), is now extended to include Bom Jardim, Cordeiro, Santa Maria Madalena, São Sebastião do Alto, and Trajano de Moraes. The commonest Ancylidae species was G. ticaga as it was observed in the Metropolitan Mesoregion by Thiengo et al. (2001).

The Afro-Asian thiarid M. tuberculatus was found in 6 out of the 15 municipalities, in areas with dense populations inhabiting both polluted and non-polluted, lotic and lentic waterbodies. The most frequently found ampullariid was Pomacea sp. which is probably a new species.
The records of $D$. lucidum shedding echinostome cercaria and $A$. nordestensis shedding strigid cercaria are, respectively, the first and second records of these species acting as intermediate hosts of trematodes in Brazil.

Due to the limitation of logistic resources available to Funasa in the last years, the number of positive schistosomiasis cases are probably underestimated. The results of the stool survey in Duas Barras and Sumidouro indicate that transmission still goes on in these municipalities and both are recognized as low transmission sites.

\section{ACKNOWLEDGEMENTS}

To Regional Directory of National Health Foundation of Rio de Janeiro, in 1984, for sending us samples of snails from several localities of the state, to Heucler FR Silva (Funasa/RJ) for providing the results of parasitological surveys, and to Lygia dos Reis Corrêa, Head of the Department of Malacology, for the facilities supplied throughout this investigation.

\section{REFERENCES}

IBGE-Instituto Brasileiro de Geografia e Estatística 1995. Síntese da documentação histórico-administrativa e geográfica dos Estados do Brasil - Rio de Janeiro, Fundação Instituto Brasileiro de Geografia e Estatística, Rio de Janeiro.

Paraense WL 1966. The synonymy and distribution of Biomphalaria peregrina in the Neotropical Region. Rev Brasil Biol 26: 269-296.

Paraense WL 1972. Fauna Planorbídica do Brasil. In CS Lacaz, RG Baruzzi, W Siqueira Jr (eds), Introdução à Geografia Médica do Brasil, Edgard Blücher \& Univ. São Paulo, São Paulo, p. 213-239.

Paraense WL 1986. Distribuição dos caramujos no Brasil. In FA Reis, I Faria, N Katz (eds), Modernos Conhecimentos 
sobre Esquistossomose Mansônica, Biblioteca da Academia Mineira de Medicina, Belo Horizonte, p. 117-128.

Paraense WL, Corrêa LR 1973. Susceptibility of Biomphalaria peregrina from Brazil and Ecuador to two strains of Schistosoma mansoni. Rev Inst Med Trop São Paulo 15: 127-130.

Santos SB, Monteiro DP, Fernandez MA, Thiengo SC 1999.

Primeiro registro de Antillorbis nordestensis (Lucena) (Mollusca, Gastropoda, Planorbidae) para a Ilha Grande, Angra dos Reis, Rio de Janeiro. Rev Bras Zool 16: 257-259.

Schell S 1970. How to Know the Trematodes, WMC Brown Co.
Publisher, Dubuque, $355 \mathrm{pp}$

Thiengo SC, Fernandez MA, Boaventura MFF, Stortti MA 1998. A survey of gastropods in the Microrregião Serrana of Rio de Janeiro, Brazil. Mem Inst Oswaldo Cruz 93 (Suppl. I): 233-234.

Thiengo SC, Fernandez MA, Boaventura MF, Grault CE, Silva HFR, Mattos AC, Santos SB 2001. Freshwater snails and schistosomiasis mansoni in the State of Rio de Janeiro, Brazil: I - Metropolitan Mesoregion. Mem Inst Oswaldo Cruz, 96 (Suppl.): 177-184. 